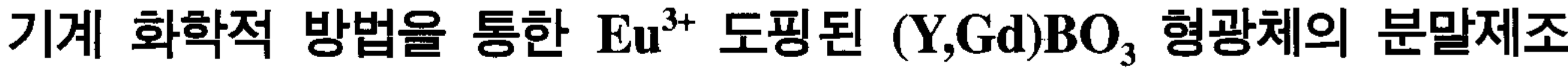

\author{
원희섭 · 이완재 · 김제석 ${ }^{a} \cdot$ 홍근영 ${ }^{a} \cdot$ 이근재 ${ }^{b} \cdot$ 좌용호 ${ }^{b, *}$ \\ 한양대학교 금속재료공학과, ${ }^{a} \mathrm{LG}$ 전자기술원, ${ }^{b}$ 한양대학교 정밀화학공학과
}

\section{Synthesis of $\mathrm{Eu}^{3+}$ Doped $(\mathrm{Y}, \mathrm{Gd}) \mathrm{BO}_{3}$ Powder by Mechanochemical Process}

\author{
Hee Sub Won, Wan Jae Lee, Je Seok Kim ${ }^{a}$, Gun Young Hong ${ }^{a}$, Kun-Jae Lee ${ }^{b}$ and Yong-Ho Choa ${ }^{b, *}$ \\ Department of Metallurgy and Materials Science, Hanyang University, Ansan 426-791, Korea \\ ${ }^{a}$ LG Electronics Advanced Research Institute, Seocho-gu, Seoul 137-724, Korea \\ ${ }^{b}$ Department of Fine Chemical Engineering, Hanyang University, Ansan 426-791, Korea
}

(Received March 7, 2008; Accepted April 15, 2008)

\begin{abstract}
The mechanochemical process were employed to prepare the red phosphors (Y,Gd)BO $\mathrm{BO}_{3}: \mathrm{Eu}^{3+}$. The main factors affecting particle size, particle distribution, and luminescent properties of the product were investigated in details. Particles sized around $200-600 \mathrm{~nm}$ are formed after intensive milling. The phosphors were characterized by X-ray diffraction (XRD), scanning electron microscope (SEM) and photoluminescence spectrum. Results revealed that phosphors with different morphology, small particle size and high luminescence intensity could be obtained by mechanochemical process.
\end{abstract}

Keywords : Red phosphor, Mechanochemical process, Photoluminescence

\section{1. 서 론}

플라즈마 디스플레이 패널(Plasma Display Panel; $\mathrm{PDP})$ 에 사용되는 형광체는 발광 메커니즘에서 PDP 의 색을 구현하기 위한 중요한 물질이다[1]. 형광체 는 진공자외선(VUV)에 의해 여기 상태가 되고 이 러한 여기에 의해 발광을 하는 PDP용 형광체로 쓰 이기 위해 화학적 안정성을 가지면서 제조가 쉬운 희토류 이온들이 도핑된 산화 화합물들이 주목을 받 아왔다. 그 중에서 최근 붕산염(borate)계 물질들이 높은 진공자외선 투명도, 화학적인 안정성, 뛰어난 광학적 손상 한계값(damage thresholds)등의 광학적 성질들로 인하여 큰 관심을 받고 있다[2]. 붕산염계 형광체들 중에서 특히 $(\mathrm{Y}, \mathrm{Gd}) \mathrm{BO}_{3}: \mathrm{Eu}^{3+}$ 형광체는 $147 \mathrm{~nm}$ 의 진공자외선에 의해 여기 될 때 높은 발 광 효율 특성을 보이기 때문에 PDP용 컬러 화상에 들어가는 적색의 형광체로 널리 쓰이고 있다[3]. 양 자구속(Quantum confinement)효과에 의하여 나노
크기의 형광체는 밴드갭이 중가되고 전자정공 쌍이 나노 크기 형광체에 갇힘으로써 활성제(activator) 이온에 의해 포획된 후 재결합되는 속도가 증가하 게 되므로 발광 효율이 증가된다. 나노 형광체는 나 노 결정의 부피에 대한 표면의 비가 상당히 크므로 표면 비발광 경로에 의한 발광 효율 감소가 쉽게 관측된다. 따라서 이와 같은 표면 비발광 부위를 줄 이고 양자구속효과를 유지하기 위해서 형광체의 표 면을 계면 활성제로 처리하는 경우도 있다. 이러한 나노 형광체의 입자 크기 특성은 디스플레이로의 응 용에 있어서 분말의 크기가 미세해지면 보다 얇고 치밀한 고효율의 형광막을 얻을 수 있어 디스플레 이의 성능을 향상시키는데 기여할 수 있다. 고해상 도 디스플레이 구현에 있어서 형광체의 평균 입자 크기가 매우 중요하고 우수한 발광 특성을 위해서 형광체는 반드시 좁은 입자 크기의 분포, 비응집 입자 형태, 균질한 형상을 가지고 있어야 한다.

현재 PDP에 Red계로 쓰이고 있는 $(\mathrm{Y}, \mathrm{Gd}) \mathrm{BO}_{3}: \mathrm{Eu}^{3+}$

*Corresponding Author : [Tel : +82-31-400-5650; E-mail : choa15@hanyang.ac.kr] 
형광체는 고온에서의 $\mathrm{B}_{2} \mathrm{O}_{3}$ 의 증발을 고려하여 산화붕 소(boric oxide)를 목표하는 조성보다 10-50\% 정도 더 첨가하는 고상반응법에 의해 상대적으로 높은 온 도 $\left(1100-1400^{\circ} \mathrm{C}\right)$ 에서 합성된다[4]. 이와 같은 고상반 응법은 이트륨, 가돌리늄, 유로퓸과 같은 고가의 희토 류 성분의 사용량이 크며, $1100^{\circ} \mathrm{C}$ 이상의 고온에서 열처리되므로 고온에서 붕소 성분이 용융되어 형광체 입자의 응집을 초래하며 구형 입자 형상을 얻기 어렵 다[5]. 또한, 하소 후에 재분쇄 과정을 거치게 되는대, 이는 형광체의 표면에 손상을 입히게 되고 분쇄 과정 에서 불순물이 혼입되어 발광 강도의 손실을 가져온 다[6]. 한편, 최근에는 상기와 같은 종래의 방법으로 형광체를 제조하였을 때 바테라이트(vaterite) 타입의 방 해석(calcite) 구조로의 상변이(phase transition)로 인해 열 이력현상(thermal hysteresis)이 발생되기 때문에 바 테라이트(vaterite)상의 결정 모양이 불완전하다는 것 이 보고된 바 있다[7]. 이러한 문제점들을 해결하기 위해서 낮은 온도에서 미세한 입자 크기로 합성할 수 있고 높은 발광 효율을 얻을 수 있는 분무열분해 (aerosol pyrolysis), 수열합성(hydrothermal), 졸-겔(solgel process), 공침(co-precipitation) 방법들이 연구되고 있다[8].

본 연구에서는 물리적 혼합뿐만 아니라 화학반응 도 함께 이용한 기계화학적 공정(mechanochemical process; $\mathrm{MCP}$ )으로 형광체 분말을 합성하였다. 기 계화학적 공정은 연속적인 볼과 분말간의 강한 기 계적 작용으로 고에너지 볼밀에 의한 입자들 간의 반응이 계면 근처에서 되풀이 되어 화학적인 변화 를 가지게 되는 원리를 이용한 공정으로 금속, 세라 믹 나노분말 뿐만 아니라 이들의 복합분말을 합성 할 수 있는 장점이 있어 그 응용이 크게 확대되고 있는 새로운 분말 합성 공정이다. 진동 밀링 중에 화학반응이 일어나고 막대한 진동과 충돌 에너지로 인하여 서브마이크론 이하의 미세한 입자들이 얻어 진다. 또한 후속공정에서 열처리 온도를 낮출 수 있 고 입자의 반응성과 환경적인 측면에서 여러 가지 장점을 가지고 있다[9]. 따라서 본 연구에서는 $(\mathrm{Y}, \mathrm{Gd}) \mathrm{BO}_{3}: \mathrm{Eu}^{3+}$ 적색 형광체의 제조에 있어서 적색 형광체의 발광 특성을 개선시키기 위해 볼밀 조건 과 열처리 온도에 따른 형광체의 모양, 입도 크기 및 분포에 관한 특성과 진공자외선 여기에 따른 발 광 특성을 연구하였다.

\section{2. 실험 방법}

본 실험은 $(\mathrm{Y}, \mathrm{Gd}) \mathrm{BO}_{3}: \mathrm{Eu}^{3+}$ 적색 형광체 분말을 합 성하기 위해 그림 1 에서와 같은 기계화학적 방법을 사용하여 합성하였으며, 제조공정 중에 기존의 열처 리 온도 $\left(1100-1400^{\circ} \mathrm{C}\right)$ 보다 낮은 온도 $\left(1100^{\circ} \mathrm{C}\right.$ 이하) 에서 형광체를 합성하여 특성을 비교하였다. 우선 $\mathrm{Eu}$ 가 $0.05 \mathrm{~mol} \%$ 첨가된 $\left(\mathrm{Y}_{0.6}, \mathrm{Gd}_{0.35}\right) \mathrm{BO}_{3}: \mathrm{Eu}_{0.05}$ 의 조성이 되도록 칭량하였으며, 모체(host)의 재료로는 염화가 돌리늄 $\left(\mathrm{GdCl}_{3} ; 99.9 \%\right.$, Kojundo chemical Laboratory Co., LTD), 염화이트륨 $\left(\mathrm{YCl}_{3} ; 99.99 \%\right.$, Aldrich Chem. Co.), 붕산 $\left(\mathrm{H}_{3} \mathrm{BO}_{3} ; 99.9 \%\right.$, Kojundo chemical Laboratory Co., LTD)을 사용하였으며, 활성제 (activator)로는 염화유로품 $\left(\mathrm{EuCl}_{3} ; 99.9 \%\right.$, Aldrich Chem. Co.)을 사 용하였다. 지르코니아 용기와 볼을 사용하였고 볼(지 름 $10 \mathrm{~mm}$ )과 분말의 비는 $10: 1$ 로 하였다. 이 용기 를 진동밀(SPEX Co., 8000M Mixer/Mill)에 넣고 $1060 \mathrm{cycles} / \mathrm{min}$ 의 고에너지로 4 시간 동안 밀링하였 다. 밀링 후에 혼합분말을 알루미나 보트(alumina boat)에 채워 박스로(box furnace)에 장입하였다. 승온 속도를 $5^{\circ} \mathrm{C} / \mathrm{min}$ 으로 하였고 대기분위기에서 $500^{\circ} \mathrm{C} 1$ 시간 유지시킨 후 각각 $800,900,100,1100^{\circ} \mathrm{C}$ 온 도로 2 시간 동안 하소하여 단일상(single phase)을 얻고자 하였다. 이때 보론(B, boron)의 휘발 억제와 안정화를 위해 $500^{\circ} \mathrm{C}$ 에서 1 시간 유지하였다. 최종적 으로 하소처리한 각 분말을 $\mathrm{FE}-\mathrm{SEM}(\mathrm{JEOL} \mathrm{Co}$., JSM-6330F, Japan)으로 입자 크기와 형상을 관찰하였 고, XRD(Rigaku Co., MAX-2500)로 단일상의 형성 여부를 조사하였다. 분말의 크기를 확인하기 위해서

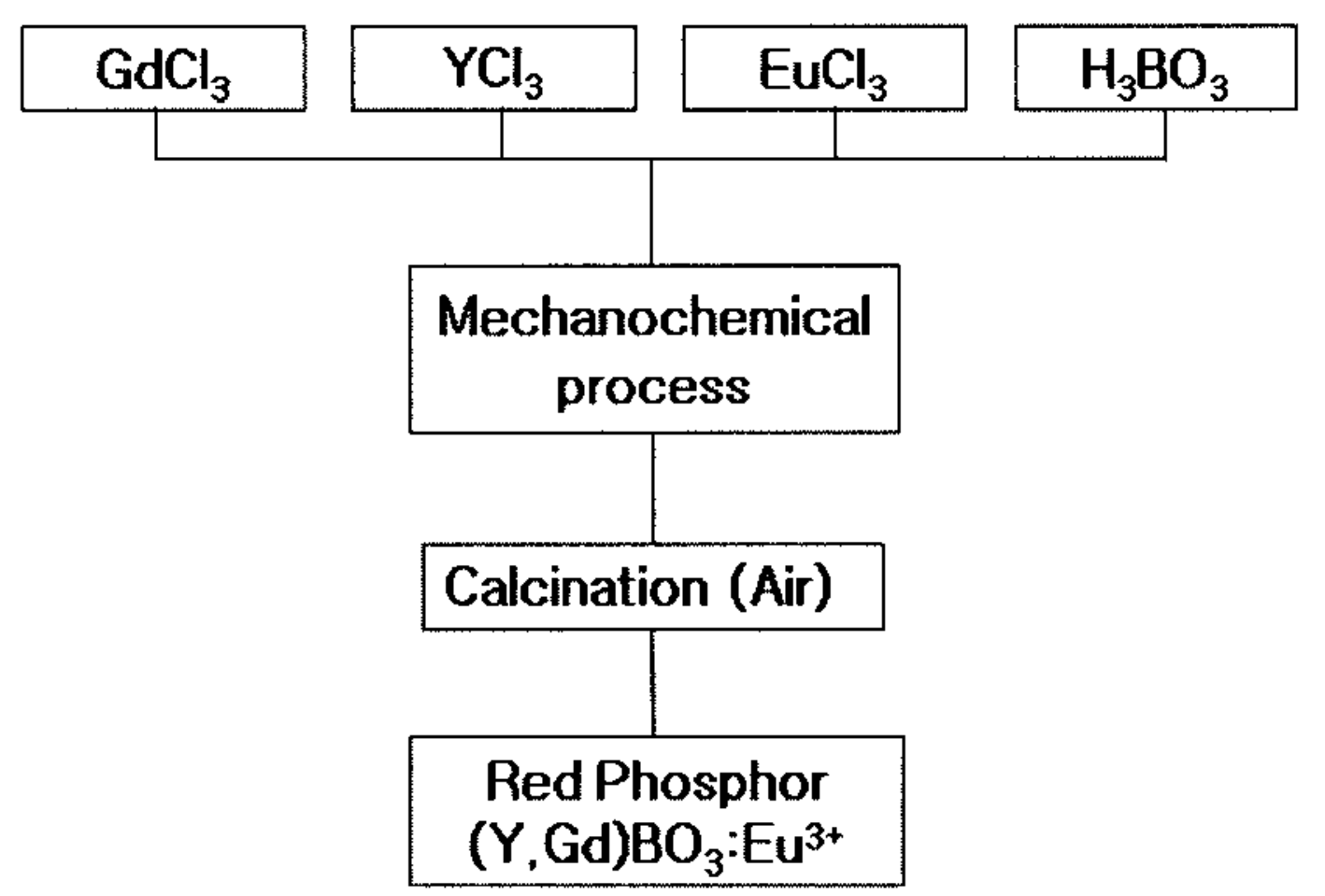

Fig. 1. Experimental procedure of red phosphor (Y,Gd) $\mathrm{BO}_{3}: \mathbf{E u}^{3+}$. 
LPA(ELS-8000, Photal)을 이용하였고, 최종적으로 $\mathrm{PL}$ 분광계(LS50B, Perkin Elmer)로 형광체의 발광 특성을 분석하였다.

\section{3. 결과 및 고찰}

분말은 모두 기계화학적 방법과 소성을 통하여 합 성되었으며 소성 열처리 온도조건은 $800^{\circ} \mathrm{C}, 900^{\circ} \mathrm{C}$, $1000^{\circ} \mathrm{C}, 1100^{\circ} \mathrm{C}$ 이었다. 그림 2에서 볼 수 있듯이 최 종 합성된 $(\mathrm{Y}, \mathrm{Gd}) \mathrm{BO}_{3}: \mathrm{Eu}^{3+}$ 적색 형광체의 경우 약 200-600 nm의 입자 크기를 가지고 있었다. 열처리 온도가 $800^{\circ} \mathrm{C}$ 에서 $1000^{\circ} \mathrm{C}$ 로 증가함에 따라 분말입도 는 중가하지만 $1100^{\circ} \mathrm{C}$ 에서는 $1000^{\circ} \mathrm{C}$ 와 큰 차이가 관찰되지 않았다. 열처리 과정에서 반응을 촉진시키 는 붕산염의 영향으로 인해 구형의 형태가 깨어지고 불규칙한 분말들이 얻어졌으며 입자들 간에 화학적인 반응이 일어나고 입자들이 매우 조밀해지면서 서로간 의 상호작용으로 인해 응집도 많이 일어났다[4].

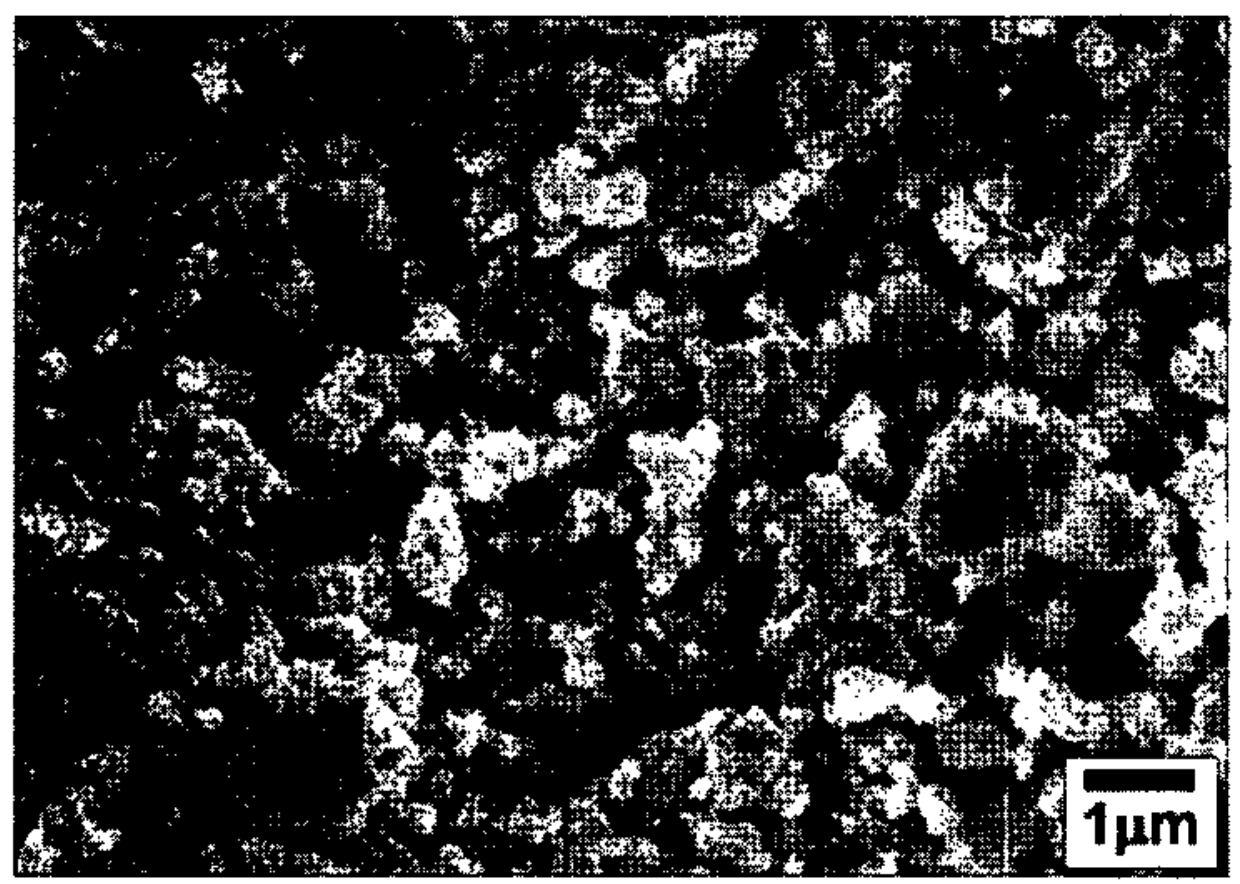

(a)

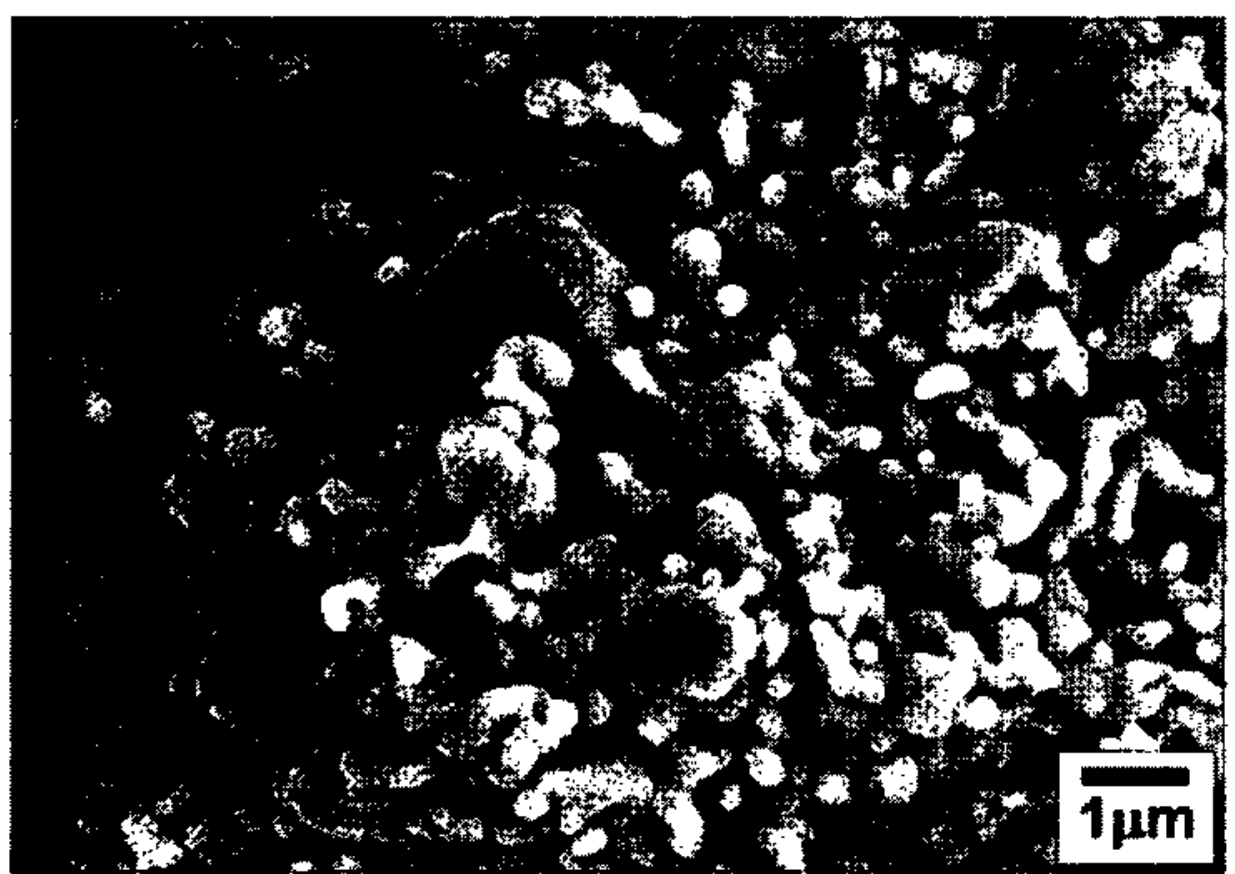

(c)
합성된 $(\mathrm{Y}, \mathrm{Gd}) \mathrm{BO}_{3}: \mathrm{Eu}^{3+}$ 적색 형광체의 경우 높은 결정도(crystallinity)를 보였으며, 열처리 온도에 따라 결정의 크기 및 결정도가 변화하는 것을 확인하였다. 그림 3(a)은 합성한 $(\mathrm{Y}, \mathrm{Gd}) \mathrm{BO}_{3}: \mathrm{Eu}^{3+}$ 를 $800^{\circ} \mathrm{C}, 900^{\circ} \mathrm{C}$, $1000^{\circ} \mathrm{C}, 1100^{\circ} \mathrm{C}$ 에서 4 시간 동안 대기분위기에서 열 처리한 경우의 XRD 결과를 나타낸 것이다. 형광체의 결정구조는 공간군(space group) $\mathrm{P}_{3} / \mathrm{mmc}$ (No. 194) 의 육방정계(hexagonal)구조를 하고 있었다. 합성된 $(\mathrm{Y}, \mathrm{Gd}) \mathrm{BO}_{3}: \mathrm{Eu}^{3+}$ 형광체는 열처리 온도별로 두드러진 변화가 관찰되지 않았고 모두 같은 $\mathrm{X}$ 선 회절 패턴을 보였다. 그림 3(b)은 열처리 온도 증가에 따른 주피크 $\left(2 \theta=27.180^{\circ}\right)$ 의 반가폭(FWHM)의 변화를 나타내었다. 온도증가에 따라 반가폭이 0.233 에서 0.196 로 점차 감소하였고 마찬가지로 다른 피크들의 반가폭도 감소 하는 경향을 보였다. Scherrer 식[10]을 토대로 계산 한 결정 크기(crystalline size) 또한, $800^{\circ} \mathrm{C}$ 에서 39 $\mathrm{nm}, 1100^{\circ} \mathrm{C}$ 에서 $50 \mathrm{~nm}$ 로 커짐을 알 수 있었다. 이 로부터 그림 2에서 명확하게 관찰할 수 없었던 온도

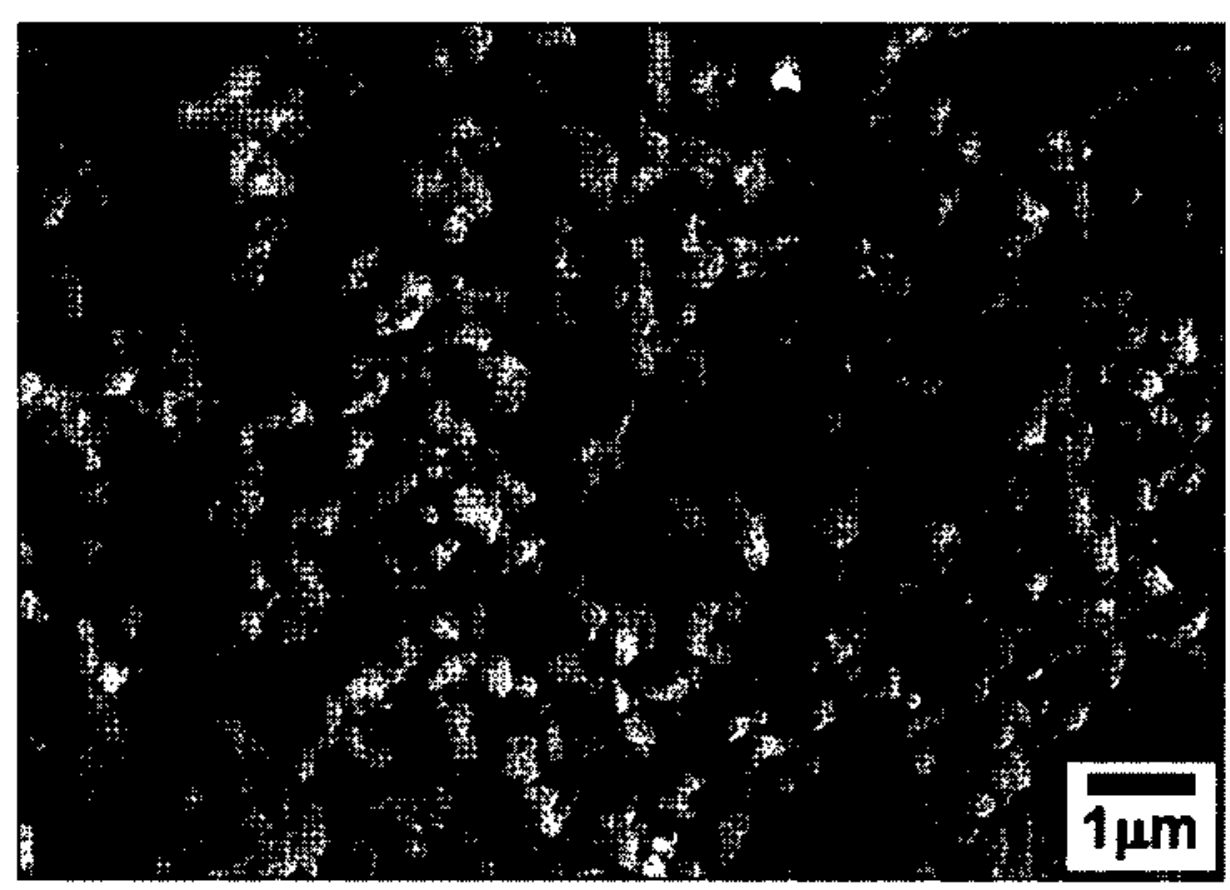

(b)

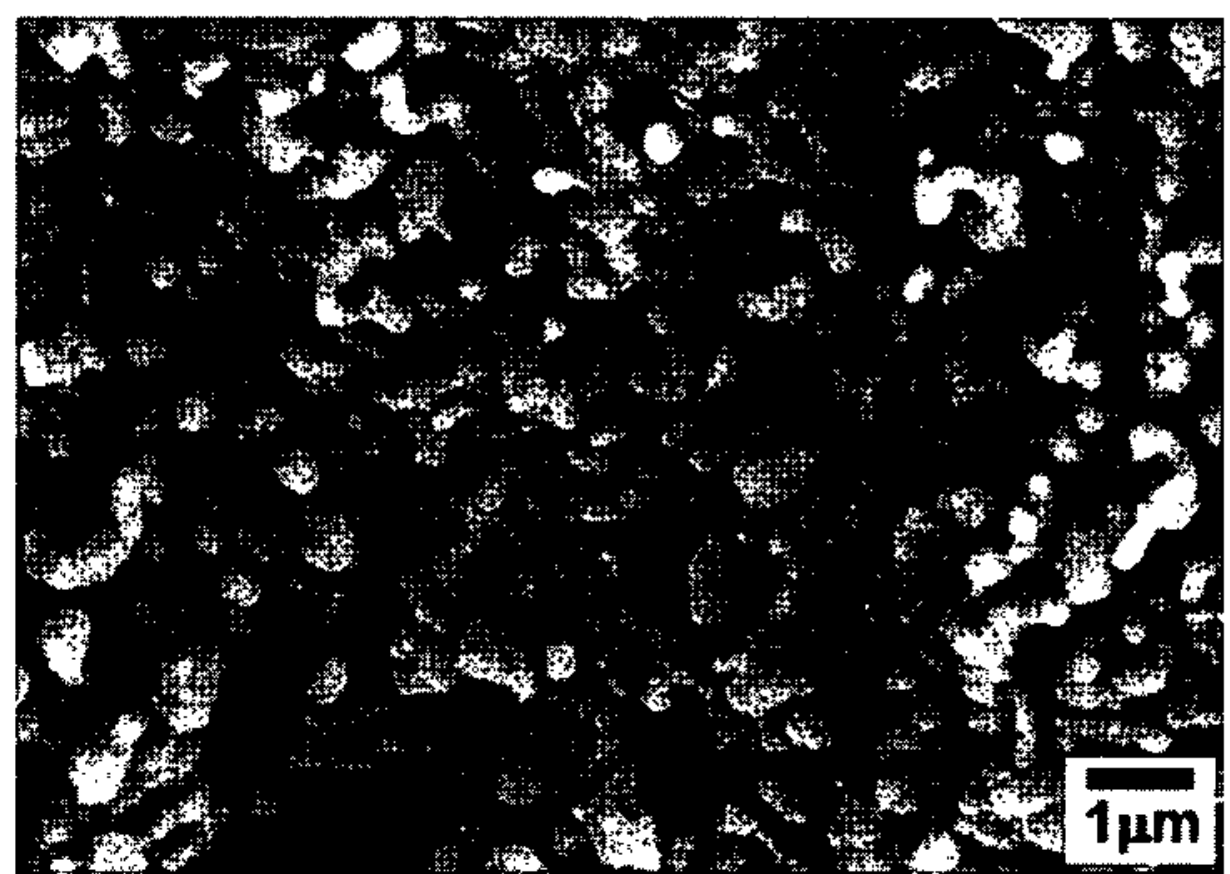

(d)

Fig. 2. FE-SEM photograph of $(\mathrm{Y}, \mathrm{Gd}) \mathrm{BO}_{3}: \mathrm{Eu}^{3+}$ red phosphor (calcination temperature : (a) $800^{\circ} \mathrm{C},(\mathrm{b}) 900^{\circ} \mathrm{C},(\mathrm{c}) 1000^{\circ} \mathrm{C}$, and $(\mathrm{d}) 1100^{\circ} \mathrm{C}$ ). 
(a)

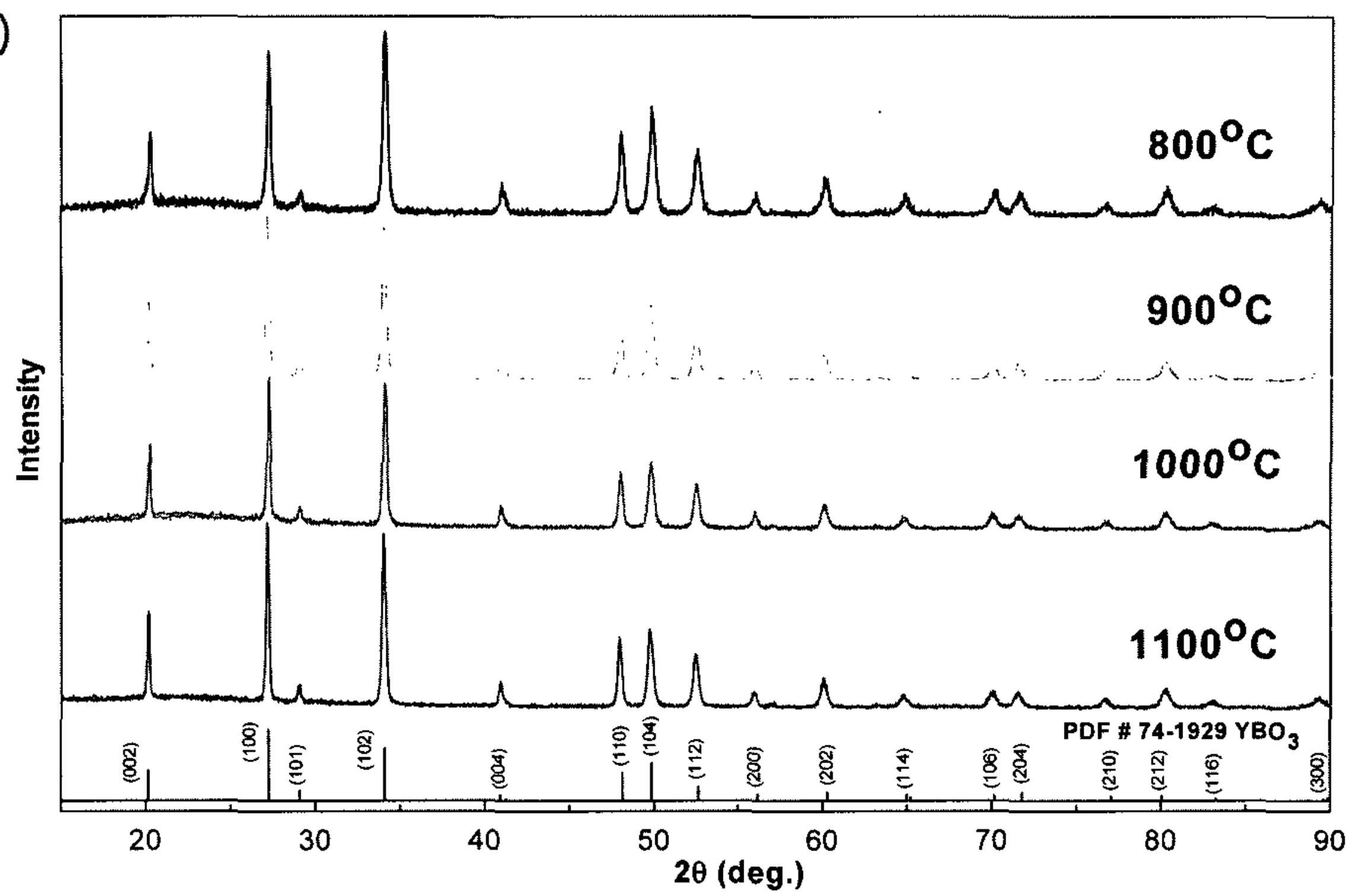

(b)

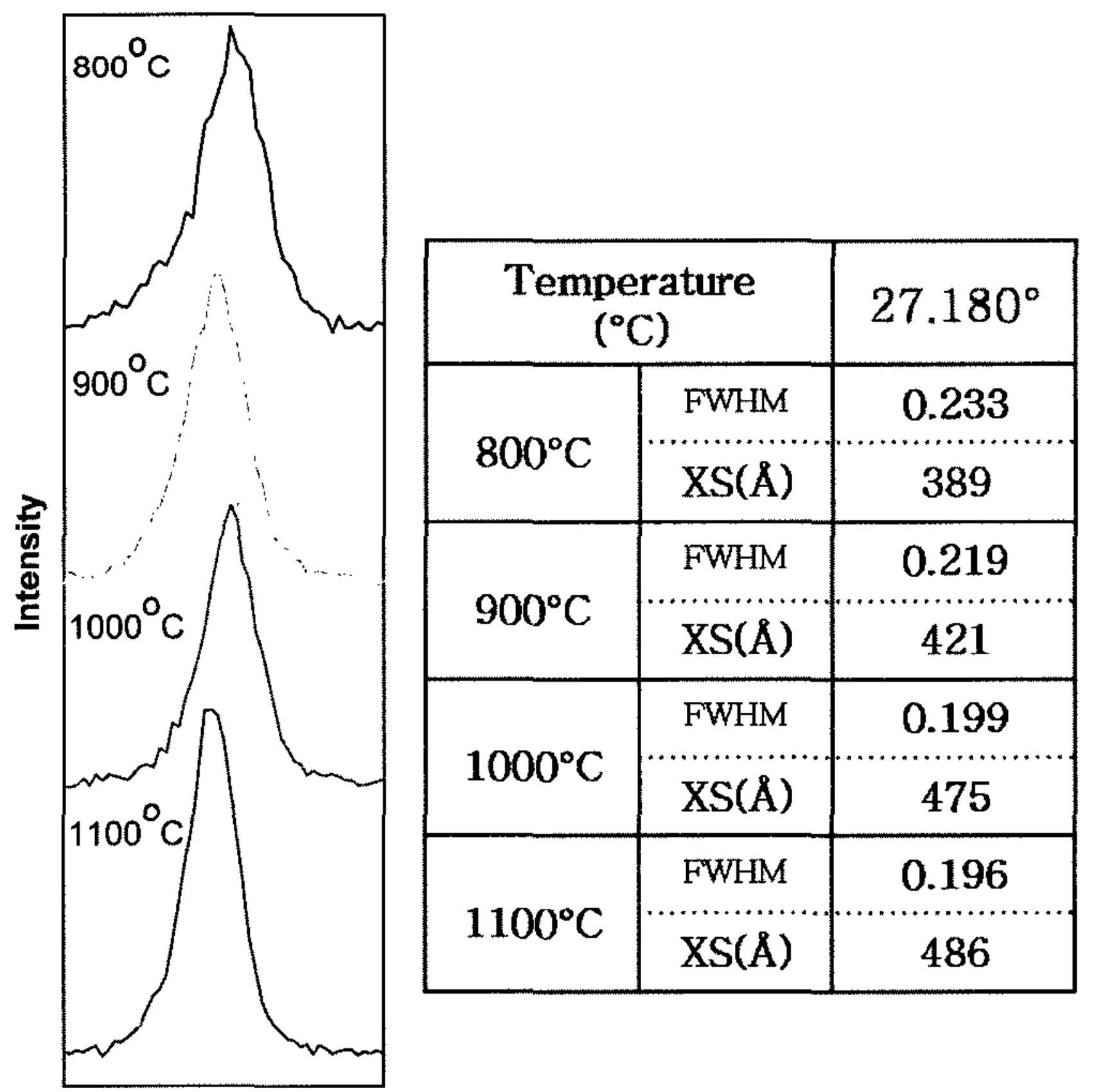

Fig. 3. XRD data of $(\mathrm{Y}, \mathrm{Gd}) \mathrm{BO}_{3}: \mathrm{Eu}^{3+}$ red phosphor according to calcination temperature : (a) wide range of $10^{\circ}-90^{\circ}$ and (b) focused range of the main peak $\left(26.5^{\circ}-27.5^{\circ}\right)$ and Half-Width(FWHM) with calculated grain size of main peak.

증가에 따른 입자 크기의 증가를 확인 할 수 있었고 열처리 온도가 높을수록 결정상의 증가와 함께 입자 크기가 증가한다는 것을 알 수 있었다. 또한 200-600 $\mathrm{nm}$ 의 SEM 상에서의 입자 크기가 2차 입자(secondary particle) 크기임을 알 수 있었다.

그림 4 에서 보듯이 $(\mathrm{Y}, \mathrm{Gd}) \mathrm{BO}_{3}: \mathrm{Eu}^{3+}$ 적색 형광체의 PL 특성을 확인한 결과, 기존 형광체와 유사한 발광 강도를 보였으며, 주 발광 피크도 정확히 일치하였다. 

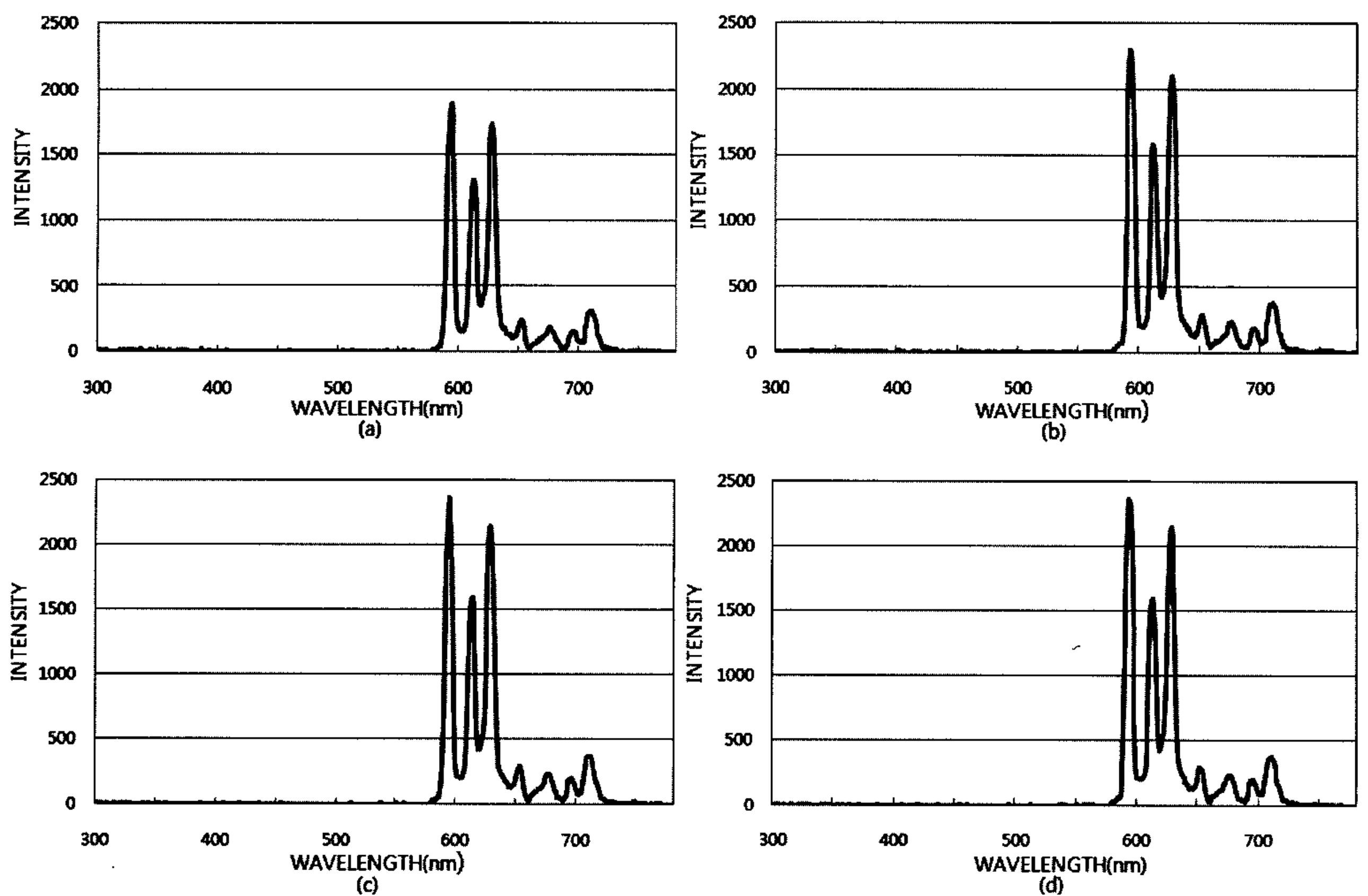

Fig. 4. PL data of (Y,Gd)BO $\mathrm{BH}^{3+}$ red phosphor (calcination temperature : (a) $800^{\circ} \mathrm{C}$, (b) $900^{\circ} \mathrm{C},(\mathrm{c}) 1000^{\circ} \mathrm{C}$ : and (d) $\left.1100^{\circ} \mathrm{C}\right)$.

이는 고에너지 밀링 시에 활성제가 형광체 모체 사이 에 효과적으로 분산되어 낮은 열처리 온도에도 쉽게 형광체 모체의 격자 속으로 침투할 수 있는 조건이 형성되었기 때문이라 사료된다. 주 발광 파장은 612 $\mathrm{nm}$ 로 $\mathrm{CIE}$ 색좌표는 $\mathrm{x}=0.6371, \mathrm{y}=0.3532, \mathrm{Y}=6.87$ 을 나타냈다. 형광체의 입자 크기를 미세화하기 위하여 통상적으로 밀링 등의 분쇄 과정을 수행하고 있으나 분쇄 시 불순물이나 결함이 생성되고 구조적인 변화 를 초래하는 결정의 변화와 파괴에 의해 형광체의 발 광 특성이 저하되고 있다[11]. 이외에도 결정도의 감 소와 표면에너지 증가로 인한 응집을 초래하고 있다. 그러나 그림 1에서 보듯이 본 연구에서는 기계화학적 공정을 이용하여 형광체 제조 공정을 단순화 하였으 며 최종 형광체 분말의 순도를 $99 \%$ 이상으로 유지하 여 불순물이나 결함에 의한 발광 특성 저하를 최소화 하였다. 고에너지 볼밀로 인한 입자 표면에 가해지는 매우 강한 기계적 작용은 그 기계적인 힘이 접촉하는 입자 표면의 근처에서 물리적인 변화와 동시에 화학 적인 변화도 초래하였고, 이로 인하여 기존의 고상법 에서 요구되어지는 열처리 온도보다 $200^{\circ} \mathrm{C}$ 낮은 온 도에서도 상용 형광체와 유사한 형광특성을 가지는 형광체를 제조할 수 있었다.
발광은 활성제(activator)인 $\mathrm{Eu}^{3+}$ 이온의 ${ }^{5} \mathrm{D}_{0} \rightarrow{ }^{7} \mathrm{~F}_{\mathrm{j}}$ $(\mathrm{j}=0-6)$ 전이에 의한 것이며 그 중 $593 \mathrm{~nm}$ 에서의 가 장 큰 피크는 ${ }^{5} \mathrm{D}_{0} \rightarrow{ }^{7} \mathrm{~F}_{1}$ 전이에 기인한 것으로 $\mathrm{Eu}^{3+}$ 이 온이 대칭 구조를 갖는 자리에 위치할 때 나타난 것 이고 612 와 $628 \mathrm{~nm}$ 에서의 두 피크는 ${ }^{5} \mathrm{D}_{0} \rightarrow{ }^{7} \mathrm{~F}_{2}$ 전이 에 기인한 것으로서 $\mathrm{Eu}^{3+}$ 이온이 비대칭 구조를 갖는 자리에 위치할 때 나타난다. 이것은 $\mathrm{YBO}_{3}$ 결정에서 이트름(Yttrium) 자리가 대칭과 비대칭 구조를 동시에 갖고 있기 때문이다[11-13]. 그러나 그림 4에서 보듯 이 열처리 온도가 증가할수록 발광 특성이 증가하였 으며 이는 열처리 온도의 증가에 따른 형광체의 결정 성 중가와 입자 형상 및 표면 특성에 기인한 것으로 사료된다.

고상반응법으로 $(\mathrm{Y}, \mathrm{Gd}) \mathrm{BO}_{3}: \mathrm{Eu}^{3+}$ 적색형광체를 제조 하기 위해서는 $1100^{\circ} \mathrm{C}$ 의 고온의 반응온도가 요구되 고 있는 반면, 기계화학적 방법을 사용하면 상온에서 볼밀 후 비교적 저온인 $900^{\circ} \mathrm{C}$ 에서 열처리하여 형광 체를 제조 할 수 있고 이로 인해 보론 양의 보정 및 융제(flux)역할을 하는 붕산(boric acid)을 첨가하지 않아도 되기 때문에 공정이 단순해지고 세척에 의한 불순물 등의 혼입이 적어지게 된다. 또한 기계화학적 방법을 사용하면 고에너지 볼밀에 의해 $1 \mu \mathrm{m}$ 이하의 
미세한 크기의 형광체 제조가 가능하여 향후 고해상 도의 PDP, 형광램프, 복사용 램프 등을 비롯한 많은 분야에 효과적으로 활용될 것으로 기대된다.

\section{4. 결 론}

기계화학적 방법으로 $(\mathrm{Y}, \mathrm{Gd}) \mathrm{BO}_{3}: \mathrm{Eu}^{3+}$ 적색형광체를 합성하였으며 볼밀 후 열처리한 형광체는 열처리 온 도 증가에 따라 결정상의 증가와 함께 입자 크기가 증가하는 것을 확인할 수 있었다. 입자는 약 200-600 $\mathrm{nm}$ 의 크기로 분포하고 있었으며 열처리 온도 증가에 따라 결정성의 향상과 함께 입자 크기가 증가하는 것 을 확인할 수 있었다. 열처리 온도 중가에 따라 발광 강도가 증가하였고 특히 $900^{\circ} \mathrm{C}$ 에서의 발광 특성도 기 존의 고상법(하소온도: $1100-1300^{\circ} \mathrm{C}$ )으로 제조된 형 광체의 발광 특성과 비교하여 그 특성이 크게 떨어지 지 않음을 확인하였다. 이상의 결과로부터 기계화학 적 공정과 응집을 해소하기 위한 다양한 분산제를 사 용한다면 원하는 크기의 결정 특성 및 매우 균일한 입도를 갖는 $(\mathrm{Y}, \mathrm{Gd}) \mathrm{BO}_{3}: \mathrm{Eu}^{3+}$ 적색형광체 제작이 가능 할 것으로 생각한다.

\section{감사의 글}

본 연구는 산업자원부 차세대 신기술 개발사업의 일환인 고기능성 나노분말소재핵심기술 사업과 에너 지관리공단 에너지 자원기술개발사업의 지원에 의하 여 수행되었습니다.

\section{참고문헌}

[1] J. K. Berkowitz and J. A. Olsen: J. Luminescence., 50 (1991) 111.

[2] Yuhua Wang, Kyota Uheda, Hirotsugu Takizawa, Ushirozawa Mizumoto and Tadashi Endo: J. Electrochem. Soc., 148 (2001) 430.

[3] S. Ekambaram and M. Maaza: Journal of Alloys and Compounds, 395 (2005) 132.

[4] F. J. Avella, O. J. Sovers and C. S. Wiggins: J. electrochem. Soc., 114 (1976) 613.

[5] A. Mayolet, J. C. Krupa, L. Gerard and P. Martin: J. Mater. Chem. Phys., 31 (1992) 107.

[6] T. Kojma: Phosphor Handbook, S. Shionoya and W. M. Yen (Ed.), CRC Press, Boca (1998) 623.

[7] M. Ren, J. H. Lin, Y. Dong, L. Q. Yang and M. Z. Su: Chem. Mater., 11 (1999) 1576.

[8] Huasheng Lai, Baojiu Chen, Wu Xu, Xiaojun Wang, Yanmin Yang and Qing Meng: Journal of Alloys and Compounds, 395 (2005) 181.

[9] K. S. Venkataram and K. S. Narayanan: Powder Technology, 96 (1998) 190.

[10] B. D. Cullity and S. R. Stock: Elements of X-ray Diffraction, Prentice Hall, 3rd Edition, New Jersey (2001).

[11] G. Blasse and B. C. Grabmarie: Luminescent Materials, Spriger-Verlag, New York (1994) 41.

[12] S. ShIonya and W. M. Yen: Phosphor Handbook, CRC Press, (1998) 261.

[13] G. Chadeyronm, M. El-Ghozzi, R. Mahion, A. Arbus, and J. C. Cousseins: J. Solid State Chem., 128 (1997) 261. 